Finally if $A$ were dual w.r.t. $\|\cdot\|, A_{2}$ would be dual by (iii). This contradicts part (2).

\title{
BIBLIOGRAPHY
}

1. B. Barnes, Doctoral dissertation, Cornell University, Ithaca, N. Y., 1964.

2. I. Kaplansky, Dual rings, Ann. of Math. (2) 49 (1948), 689-701.

3. C. Rickart, Banach algebras, Van Nostrand, Princeton, N. J., 1960.

4. B. Yood, Homomorphisms on normed algebras, Pacific J. Math. 8 (1958), 373381.

CORNELl UNIVERSITY AND

University of CALIfornia, Berkeley

\section{ERRATA, VOLUME 70}

Errata to Council and Board of Trustees-1964 in the January Bulletin, p. 194. The Proceedings Committee should have read as follows:

R. C. Buck

Eldon Dyer, Chairman

Maurice Heins
Fritz John

Alex Rosenberg

George Whaples 